\title{
Historical and Legal Aspects of Implementation of Legal Incentives as the Major Regulator of Social Relations
}

\author{
Provalinsky Dmitry Igorevich ${ }^{1}$ \\ ${ }^{1}$ Law School, Krasnoyarsk State Agricultural University, Krasnoyarsk, Russia \\ Correspondence: Provalinsky Dmitry Igorevich, Law School, Krasnoyarsk State Agricultural University, \\ Krasnoyarsk, Krasnoyarsk Krai, Str. Constitution of the USSR 17 fl.166, 660049, Russia. Tel: 8-950-990-9447. \\ E-mail: dmi38288850@yandex.ru
}

Received: May 3, 2016

doi:10.20849/ajsss.v1i2.40
Accepted: May 16, 2016

Online Published: My 25, 2016

URL: http://dx.doi.org/10.20849/ajsss.v1i2.40

\begin{abstract}
The article reflects the main historical and legal aspects of the development of legal incentives, as a regulator of social relations. The author notes that social management is carried out by means of incentives and constraints expressed in the legal and moral norms. The current stage of development of society characterized by the need for States to actively socially useful behavior of participants in public relations in all spheres of life. Ideas legal incentives in the Russian theory of law related to the peculiarities of national awareness and entrenched legal and legal traditions, which are based both on the domestic and the global experience of the application of legal incentives. Analyzing the historical experience, the author notes that each stage of the development of society and the state has its own system of legal incentives, due to material and socio-cultural conditions of life and concludes that the decisive criterion in this respect is the attitude of the state to the individual, recognition of its individuality, independence of its rights. In principle, a change of power as a rule change and the system stimulants, which used this power in the arsenal of legal interventions. Analyzing the political and legal views of ancient philosophers, European thinkers XVIII - XX centuries, the author concludes that the institution of legal stimulation has evolved from simple forms to more complex ones. Studying the experience of implementation of the legal incentives accumulated throughout different periods of development of the statehood is one of the major stages in studying of the essence and accurate understanding of this many-sided phenomenon.
\end{abstract}

Keywords: encouraging legal, legal incentive, social management

Acting as a regulator of social relations, the law serves to exert influence on behaviour of the social relations participants and to adjust it in accordance with the set goals through implementing certain methods of legal influence.

Practical experience has shown that social governance is exerted through the use of incentives and restrictions expressed in the form of legal and moral standards aimed at making a compromise between different interests in order to prevent contradictoriness from becoming an insurmountable obstacle to progressive development of the society (Malko, 2004).

The current period of the Russian legal system development is characterized by growing importance of incentive methods of legal influence, that is, a set of means aimed at performance of obligations by the participants of the social relations of their own free will, at formation of a positive behaviour motivation, as well as congruence between the interests of an individual, social groups and the state.

Objective necessity for using legal incentives lies in the fact that the state and the society are in need of a proactive socially useful behaviour on the part of the participants of the social relations in all spheres of life.

A characteristic feature of legal incentives is the fact that the social relations are regulated by way of motivating the party to these relations to behave in a certain way by granting (promising) him/her additional opportunities and benefits.

The ideas of provision of legal incentives in the Russian legal theory are connected with the peculiarities of the national legal awareness, as well as with legal and political traditions established in the country. This is why these ideas reflect a certain philosophical, political and moral perspective on state legal phenomena, institutions and establishments, and are of a huge importance in terms of world view. 
The Treatise on Law and Grace written by the Kievan Metropolitan Hilarion in the $11^{\text {th }}$ century was one of the first sources to mention incentives as a means of influencing the individual behaviour. The gist of his statement is that influencing a person by way of showing mercy is more efficient than a severe punishment (Deryagina, Zhukovskaya, Svetozarsky, \& Platonov, 2011).

By mercy, he understands the means of influencing a person being opposed to punishment.

A renowned Russian philosopher of the XVIII century A.N. Radishchev singled out three groups of legal means, which ensure that «through issuing legal provisions the government can guide the actions of the citizens, namely prohibitory, motivating and preventive legal means» (Radishchev, 1949). In this sense, he attributed motivating means of influencing people to legal incentives in their modern interpretation.

A Russian jurist and left-wing politician of the end of the $19^{\text {th }}$ century - the beginning of the $20^{\text {th }}$ century N.A. Gredeskul believed that the law can influence social life not only under compulsion or through invoking punishment, but also by promising benefits and rewards (Gredeskul, 1901), or, in modern language, by implementing the means of providing legal incentives.

At the turn of the $19^{\text {th }}$ and $20^{\text {th }}$ century, the renowned Russian social and culture expert P.A. Sorokin, whilst researching the challenges of implementing the means of incentives and punishment, suggested that if the criminal law teaches about crime and punishment, then the award law should teach about feats and rewards. The reward, as he understands it, is «an act or a set of acts evoked by a feat and representing a reaction to the acts, which can be classified as acts of service» (Sorokin, 1914).

In other words, a service or expected lawful behaviour resulting in public and state approval that manifests itself in the form of rewards and bonuses (i.e. legal incentives) were placed on a par with such means of legal influence as compulsion and restriction.

Philosophical ideas of these and many other Russian scientists found their way into the Russian legislation of pre-revolutionary time (Berdyaev, 1907; Novgorodtsev, 1911; Chicherin, 1900), and are currently of great interest in terms of restoration of historical continuity of political and legal thought which was leveled during the Soviet period of development of the Russian state.

Continuity in development of political and legal thought can be defined as connection between the stages; it is dedicated to preservation of a part of the elements of the theories. It constitutes the form of mastering the experience of improving political and legal regulation, and its creative application within the new historical context under the different social circumstances, required in order not to lose the results achieved in the past (Navalny \& Romanenko, 2009).

Study of the issues associated with legal incentives in the history of Russian political and legal thought on the basis of synthesis of the results of philosophical, historical, dialectical and materialistic, technical, sociological, politological, ethical and other approaches and methods of scientific cognition holds a special meaning in defining historical continuity (transfer and acquisition of social and cultural values and traditions) as an element of national and cultural identity of the contemporary Russian society.

In this respect, despite the fact that it is being instilled by modern science to let political and legal thought of the Soviet time fall into oblivion, it is deemed appropriate to recall the words of V.I. Lenin, who noted that it is of utmost importance not to forget the basic historical connection and to approach each issue from the point of view of how this phenomenon came into existence in history, which main stages it underwent in its development, and regard what it is today based on its development through time. It will always have remains of the past, foundations of the present and rudiments of the future (Lenin, 1965-1975).

Transition of the Russian economy from the authoritarian and administrative methods to introduction and testing of the decentralized system of free entrepreneurship called not only for major alteration of legislation, but also for revision of the viewpoints concerning the forms and methods of social governance and legal influence on the processes of social development.

It is also worth noting that under the conditions of the current transformations the influence of the legal incentives has grown stronger among all the means of legal influence. We are in fact witnessing origination of the new forms of legal incentives, alteration in the content of those that already existed, expansion of the scope of their reach, and them being given a new content.

For instance, in the early 1990s grants were secured in Russia as a form of legal incentives. They were initially given by international and foreign organizations in the form of financial aid allocated for solution of social problems and for charitable purposes. Over time, this form of legal incentives has evolved and started to be 
actively used as an incentive through providing financial support for science, culture, education, physical culture and sports, health protection, environmental protection, innovation activity, etc.

The realization of a new form of legal incentives, namely, state and municipal preferences, commenced in Russia in 2009. The point of this form of incentives is to create the favoured treatment regime, aimed at motivating economic agents to implement those variants of business development, which comply with the state goals and social needs.

At the same time, at the general tendency towards expansion of the sphere of application of the incentives, the content of the tax incentives has changed as well, with them serving as one of the most efficient incentives in solving economic tasks, expanding investment activity and developing innovation activity.

Social experience indicates that such measures of approval of lawful activity and active efforts in the social sphere as rewards and incentive payments have become more widely used at the present period; the latter are not restricted to the sphere of just labour legislation any more (Presidential Decree Russian Federation, 2010).

The award system of present-day Russia is comprised of 16 orders, 3 decorations (St George's Cross, For Beneficence, For Impeccable Service), 16 medals and 62 honorary titles. State awards are the supreme form of rewarding the citizens for outstanding service in connection with protection of the Fatherland, state building, economy, science, culture, art, training, education, protection of health, life and rights of the citizens, charitable activity and other outstanding services to the State.

A form of financial support for the families entitled maternity (family) capital was introduced with the purpose of solving the demographic problem in the country (Federal law, 2007).

A form of financial support for the families entitled maternity (family) capital was introduced with the purpose of solving the demographic problem in the country (Federal law, 2007). This measure turned out to be quite efficient.

It is noted in the Annual Message of the President V.V. Putin to the Federal Assembly of the Russian Federation dated 03 December 2015 that the maternity capital programme covered over six and a half million Russian families, including those in Crimea and Sevastopol. However, the efforts, which are already being made, are not enough yet to fully recover from the demographic wound, which Russia suffered (Message from the President to the Federal Assembly, 2015). In this respect, the President of the RF suggested to prolong the maternity capital programme for at least two more years, i.e. until the end of 2018.

Legal incentives will occupy one of the central parts withing the system of the society governance mechanisms, as «the sound policy of law, by constantly guiding people's thinking and behaviour along a certain course and creating incentives for manifestation of specific motives and suppressing other motives, is capable of making the society civilized and more ethical» (Medushevsky, 1993).

A particular feature of the legal incentives operation mechanism is that it «manifests itself as the process of influence of this legal means on the will, consciousness and interests of an individual; that it is working through the inner world of a person, representing a sequence of interrelated actions: need - interest - motive - person's activity under the influence of the means of legal incentives» (Semenova, 2014).

Historical experience confirms that each stage of society development corresponds to its own system of legal incentives, which is determined by material and sociocultural living conditions. "Changes in material and sociocultural living conditions of the society lead to modification of the institution of legal incentives. This process can manifest itself through emergence of new types of incentives, disappearance of the outdated ones, filling them with new content which reflects the nature of state and social life» (Miroschnik, 2003).

We believe that the attitude of the state to the individual, recognition of their individuality, independence and rights served and continues to serve as the crucial criterion in this matter.

This statement is closely connected with the legal theory. It is corroborated by historical experience of the human society development.

So, for instance, during the era of absolutism in the European countries, recognition of the individual's rights was out of the question, and the essence of law came down to criminal penalty, implying that any man of sense shall give his rights up to the monarch in order to receive protection. At that, «immoral» (amoral) behaviour, such as licentiousness, gluttony and alcoholism, was also punishable by law (Markov, 2012).

Legal and political thought of the Age of Enlightenment (the end of the $17^{\text {th }}$ century - the middle of the $18^{\text {th }}$ century) proceeded from the realization that moral, prohibitory and class «legality» in reality did not reduce, but rather increased the number of committed crimes, and, most importantly, constricted the initiative of the people 
by strict traditional forms. Proceeding from the hypothesis that ruthless punishment does not reduce the number of crimes, the Enlightened stood up for the slogan that dozens of unpunished crimes are better than punishing just one innocent person (Markov, 2012).

The revolution in the prohibitory interpretation of the law happened in the second half of the $18^{\text {th }}$ century with emergence of the so called liberal law concept, which originated within the framework of philosophy of the Age of Enlightenment and is connected with the names of John Locke, Charles Montesquieu, Jean-Jacques Rousseau, Immanuel Kant, Cesare Bonesana-Beccaria and others. Its meaning lies in the supposition that it is neither prohibitions and repressive measures, nor restrictions of the person's behaviour that are of primary importance in the law, but, on the contrary, the rights and freedoms of the person (Lavrinenko \& Ratnikova, 2003). A French philosopher of the $20^{\text {th }}$ century Michel Foucault referred to this revolution as abandonment of «the right to die» in favour of «the right to live», when the power does not prohibit, but rather recommends and gives advice (Foucault, 1996).

We are of the opinion that these steps should be regarded as the beginning of implementation of the means of legal incentives into the social practice.

It is worth noting that one of the first people to pay attention to the positive effects of the legal incentives in the world political and legal thought was an English sociologist, jurist and founder of one of the English philosophical schools of the $19^{\text {th }}$ century, utilitarianism, Jeremy Bentham. In his Treatise on the Theory of Punishments and Rewards he wrote that one is to proceed from the following two principles when elaborating laws. The first one, the principle of maximum happiness, serves as a regulatory guide when making decisions. The second one, the principle of psychological hedonism (from the Greek word «hedonh» meaning «delight»), is a positive conception of how people behave (following their selfish goals). Thus, the law should impose punishment and appoint rewards in such a way so as to, taking the second principle of people's behaviour into account, make them act in accordance with the first principle (Bentam, 1829).

The ideas expressed by Jeremy Bentham were later supported by the French scientists. For instance, Raúl de la Grasseri thought it necessary to both reward heroism (virtue) and punish for the crime (De-la-Grasserie, 1901).

An Italian philosopher, historian, political scientist and representative of the liberal socialist movement of the $20^{\text {th }}$ century Norberto Bobbio believed that the most important novelty within the system of legal control is not so much the increase in the share of the «commands» or "positive norms» as the increasing spread of the incentives to execute the «commands» (Bobbio, 2001).

It is noteworthy that even nowadays, the issues related to study of interrelations between the state and the law with regard to development of the institution of legal incentives remain amongst the most complex and underdeveloped ones.

It can be noted in support of this presupposition that none of the known means of legal influence are aimed at the interests and making compromises between different interests (of the state and economic agents, the state and the social groups, the state and the individual etc.) in order to ensure that the existing contradictions do not turn into insurmountable obstacles to the realization of state policy and progressive development of the society.

Owing to historical peculiarities of its social and political development the Russian state always held a special leading part.

For instance, up until recently the measures of influence used with regard to the participants of social relations (citizens and economic agents) were mainly based on compulsion, prohibitions, obligations and punishment, which all rest upon the principle «permitted is only that which is allowed».

It was traditional for a rather long period of time to reward behaviour which was advantageous mainly for the state and only in certain cases - for the individual and society (Strokin, 2008).

The so called command type of social governance prevailed since Rus acquired its own statehood; the «stick» approach was literally and figuratively considered a more efficient means of achieving the goals in view than the «carrot» approach.

For instance, tsar Peter I when addressing the officials threatened them with the following: «I will strip those who make a pig's ear of the projects of their rank and have them flogged» (Knyazkov, 1990).

The expression «stick and carrot» («кнут и пряник» in Russian, which literally translates as «stick and cookie») came into use at the turn of the $19^{\text {th }}$ and $20^{\text {th }}$ century initially in the form of «плеть и пряник» («lash and cookie») and was derived from the German expression «Peitsche und Zuckerbrot» (Big dictionary of quotations and aphorisms, 2011). 
Incentives were regarded as a supplementary means of legal influence during the subsequent stages of development of the Russian state as well.

Substantial experience in the sphere of provision of legal incentives was gathered during the period of administrative and command governance, the so called Soviet period that lasted from 1917 until 1991 (there was an increase in the influence of moral and legal incentives on the person's motivation; orientation of the system of incentives towards the manufacturer; and supervision of implementation of legal incentives).

At the same time, there were also drawbacks, which called for major corrections, namely:

1) The «leftover» principle of legal incentives usage at evident priority given to legal restrictions in legislation.

2) Such a powerful means of incentives as the right to private ownership was practically brought to naught.

3) An equalizing and standardized system of legal incentives formed a corresponding system of interests of the citizens. Initiative and differentiation of the needs of certain social strata, persons, etc. was not encouraged.

4) Strict centralized nature of legal incentives implementation, which did not allow local independent action.

5) Orientation of legal incentives in manufacturing sphere towards the planning principle «from the achieved». In response to this, the tendency to receive the lowest possible plans, to conceal the reserves, etc. was being established all over the Soviet Union (Malko, 2004).

However, in the early 1990s, with transition to market relations, the role of the law, the nature and methods of legal influence on social relations and behaviour of parties to such relations started to change.

Today, the legal scholars believe that on a par with traditional restrictive means the law is intended to make better use of motivation and incentive mechanisms, which should be put into the corresponding legal standards on the law-making level and then effectively actuated in the course of enforcement of the laws (Malko, 2004).

We are inclined to insist that it is hard to name such a type of lawful activity in the present-day Russian reality that would not need legal incentives.

Historical experience confirms that when the power used to change fundamentally, the system of incentive means, which used this power as a means of legal influence, usually changed fundamentally as well.

Russian award law may serve as one of the corroborations.

Establishment and development of the award system in the USSR was based on rejection of the awards of the Russian Empire and denial of the previous experience of usage of this legal institution.

So, for instance, one of the first orders instituted in the Russian Empire, the Emperor's Order of St. Andrew the First-Called, instituted in 1699 by tsar Peter I as a distinction for the persons whose rank was not lower than that of a lieutenant general or a privy councilor, i.e. the third class according to the Table of Ranks, remained the highest award in the Russian Empire until 1917 (Kostina \& Ruchkin, 2011).

All the military ranks and privileges that came with the ranks and titles along with all the decorations, which existed in the Russian Empire were revoked on 15 December 1917 through the Decree of the Council of People's Commissars On Granting All Servicemen Equal Rights. Usage of the title «господин» (Russian for «landlord») was also revoked along with all the orders (The decrees of the Soviet power, 1957).

It was no sooner than through the Decree of the President of the Russian Federation B.I. Yeltsin No. 757 dated 01 July 1998 that the Order of St. Andrew the First-Called was reestablished as the highest Russian reward (Presidential Decree Russian Federation, 1998).

It stands to mention that origination and evolvement of the incentive measures of influence, as well as quality change in their content and forms have always been derivative of and dependent on the state of the basic relations. The extent of the legal incentives, just as the scale of compulsion, is determined at its core by the nature of state and law.

New forms of incentives emerge and get improved according to socioeconomic and political development of the society. We believe that this process is irreversible, as "the higher level of civility of the society suggests that a wider range of social life spheres will be covered by means of incentives (Strokin, 2008).

However, despite the changes which the society is undergoing, in particular replacement of socioeconomic formations, rise and fall of the states, the human nature, such substance of thoughts and feelings to which the measures of incentives fixed in the legal standards appealed throughout the whole history of existence of the mankind, remains unchanged. 
The extant teaching of one of the Brahmanic schools in Ancient India (around the period between the $2^{\text {nd }}$ century B.C. and the $2^{\text {nd }}$ century A.D.), which was taken as the basis for the Laws of Manu, still remains relevant: «to act solely out of the desire to be rewarded is not praiseworthy, but it is impossible to be fully free of such a desire: it is [this] desire that the teachings of the Vedas and performance of actions prescribed by the Vedas are based on. There is no deed here [on Earth] that would have been performed by a person completely free of the desire of a reward; all that [the person] is doing is the result of him desiring a reward» (Batyr \& Polikarpova, 2000).

When Ancient Greek philosophers Democritus, Socrates, Plato, Aristotle, Epicurus and Polybius suggested the ideas on natural legal character of state and law, they already spoke about the necessity to pay more attention to laws rather than customs in the management of state affairs. They planted the ideas of developing private ownership at the heart of development of the state, as the institution of common (collective) ownership did not provide incentives to work and cultivated laziness even during those times (Aristotle).

The goal that the state and its rulers pursue is achievement of justice. Justice, being one and common for all, should be embodied in good laws (Socrates). Ancient Greek philosophers believed that the law was defined as instructions for the crowd, assisting in holding people's envy and anger at bay (Democritus); the representatives of state authorities and the citizens must follow clear and strict laws established in the given society (Plato) (Sharapova, 2007).

At the heart of the views of Ancient Roman philosophers Cicero, Seneca, Marcus Aurelius, Epictetus, and Ancient Roman jurists Gaius, Julius Paulus and Ulpian lies the hypothesis that the law is based on justice, which is intrinsic to nature. Conformity of human laws with the natural ones is the measure of their correctness (Sharapova, 2007).

Thus, it was as far back as the ancient times that political and legal views of the philosophers already proceeded from the interpretation of state and law with regard to the mechanisms of provision of legal incentives. These phenomena are closely connected with deep internal unity and vast variety of complex interactions.

Scientific research indicates that implementation of legal incentives as the means of influencing individual's behaviour in the Russian state also has a centuries-long history (Isayev \& Zolotukhin, 1995; Chistyakova, 1984; Chistyakova, 1985; Batyr \& Polikarpova, 2000).

«Russkaya Pravda», which translates into English as «Russian Justice», (extensive edition), a legal artifact belonging to Rus during the times of feudal division, contained incentive measures on a par with the regulations on the punishment, as well as the regulations which served as an incentive (stimulus) to perform certain actions and behave in a certain way. For instance, it was stated in the commentary to Article 113 that a reward is due to be paid to the person who is to detain a kholop on the run and notify his master (Chistyakova, 1984).

The Sudebnik («Судебник» in Russian, or «Code of Law») of 1497 introduced by tsar Ivan IV mentioned such an incentive as granting personal freedom (Chistyakova, 1985).

The Sobornoye Ulozheniye (Russian: "Соборное уложение") of 1649 contained regulations aimed at stimulating the landlords' efforts in searching for no man's lands and promising to hand such lands over to the claimants as the means of rewarding them (Chistyakova, 1985).

Liberation of kholops and peasants and allotment of small estates was used as a measure of rewarding for «military service and absolute endurance» (hardships related to being held in captivity) in the second half of the $17^{\text {th }}$ century (Chistyakova, 1984).

In the $18^{\text {th }}$ century, the term «награда» («nagrada», Russian for «reward») started appearing on a par with «пожалование» («pozhalovaniye», Russian for «granting»), this was also the time when the first awards and orders came into existence.

In terms of the awards the legislation was systematized with adoption of the "Code of Instituting State Awards" in Russia in 1882. At that, incentives not stipulated by the legislation, such as monetary payments, granting of weapons, jewelry, fur coats, etc. were also used on a par with the state awards (Code of Instituting State Awards, 1882).

The measures taken within the Stolypin agrarian reform of 1906 were among the most extensive and significant means of providing legal incentives in Russia of pre-revolutionary time. These measures constituted a set of actions aimed at achieving two goals: 1) solving of the «agrarian issue» as the source of mass dissatisfaction; 2) sustainable development of agricultural industry.

The measures taken within the reform were aimed at increasing the quality of the peasants' right to land ownership, which consisted in substitution of collective and limited land ownership of rural communities with 
full-fledged private ownership of certain peasants-houseowners; exterminating archaic class civil restrictions which hampered efficient economic activity of the peasants; encouraging the peasants to buy private (especially those belonging to landlords) lands through various transactions with the Peasants' Land Bank (prevailing were easy-term loans); encouraging gaining of circulating assets by the peasant households through loaning in all of its forms (bank land mortgage loaning, loans to the members of cooperative societies and associations): support of the peasants' cooperative societies and associations.

During the Soviet period (1971-1991), legal incentives were the reflection of command and administrative methods of state and society governance.

Legal means did not permit (or permitted in the minuscule proportion) self-determination of the agents. Whilst defining the rules of behaviour, the state consolidated primarily its own will in them, thus depriving the agents of motivation in achieving the results stipulated by legal rules. In the absence of motivation for voluntary realization of the legal rules, the state implemented them by force (Strokin, 2008).

During the later Soviet period the legal incentives were consolidated primarily in the rules of labour law and were aimed at increasing labour productivity, as well as increasing the quality of the output product and strengthening labour discipline.

The 1990s saw continuation in development of the institution of legal incentives in its modern interpretation.

Studies of the origin of the institution of legal incentives show that it has evolved from the simple forms to more complex ones. At first, the incentives covered only a small range of social relations. The change in the way of life in the society and in the nature of social connections, the changes happening in the Russian state also prompted the changes in the approaches to employment of legal incentives. Within the period of over a thousand years, the legal incentives in the Russian legislation evolved from separate and unregulated elements of legal regulation to a ramified system and an entire intersectoral legal institution.

The reason for such a conclusion lies in the fact that the incentives regulating interconnected social relations are present within every branch of law without exception (public and private law, substantive and procedural law) and incorporate their own content at that.

To sum up, it stands to mention that studying the experience of implementation of the legal incentives accumulated throughout different periods of development of the statehood is one of the major stages in studying of the essence and accurate understanding of this many-sided phenomenon.

\section{References}

Batyr, K. I., \& Polikarpova, E. V. (2000). Readings on the General History of State and Law, Vol. 1. Moscow, Jurist.

Bentam, I. (1829). Qeuvtes Theorie des neines et des recompnes. Traite des preuves indiciaires. Bruxelles, Hauman.

Berdyaev, N. A. (1907). New religious consciousness and the public. Moscow, S-Pb.

Bobbio, N. (1977). From structure to function. New research in the theory of law. Milan.

Chicherin, B. N. (1900). Philosophy of Law. Moscow, Tipo-lithography Partnership I.N. Kushnerev.

Chistyakova, O. I. (1984). Russian legislation X-XX centuries. The law of Ancient Rus., Vol. 1. Moscow, Legal Literature.

Chistyakova, O. I. (1985). Russian legislation X-XX centuries. The acts of the Provincial Council, Vol. 3. Moscow, Legal Literature.

Code of Instituting State Awards. (1882). Vol. 1. Moscow, S-Pb.

De-la-Grasserie, (1901). Desprincipes sociogigues de la Griminologie. Paris.

Deryagina, V. Y., Zhukovskaya, L. P., Svetozarsky, A. K., \& Platonov O. A. (2011). Word on Law and Grace / Pre. Metropolitan John (Snychev). Moscow, Institute of Russian civilization.

Dushenko, K. (2011). Big dictionary of quotations and aphorisms. Moscow, Eksmo, INION.

Federal law Russian Federation. (2006). from 26.12.2006 number 256-FZ «On additional measures of state support for families with children». Russian legislation the Assembly, 01.01.2007, N 1 (1 ч.), ст. 19. 
Foucault, M. P. (1996). The will to truth: Beyond the knowledge, power and sexuality. The works of various years. Moscow, Publishing house Qastal. Drawing, translated from French, commentary and afterword Tabachnikova, S. \& Qastal, M.

Gredeskul, N. A. (1901). For the implementation of the teaching of law. Intelligent process required for the exercise of the right. Kharkov, KSU.

Isayev, I. A., \& Zolotukhin, I. M. (1995). The history of Russian political and legal doctrines XI-XX centuries. Moscow, AST.

Knyazkov, S. (1990). Sketches from the history of Peter the Great and his times. Moscow, Pushkino: Culture. Reprint edition reproduction of 1914.

Kostina, N. B., \& Ruchkin, A. V. (2011). State awards as a factor of social stratification and mobility. Scientific Bulletin of the Ural Academy of Public Administration: political science, economics, sociology, and law, 2(15), 212-222.

Lavrinenko, V. N., \& Ratnikova, V. P. (2003). Philosophy: Textbook for high schools. Moscow, Unity-Dana.

Lenin, V. I. (1965-1975). Full composition of writings, Vol. 39. Moscow.

Malko, A. V. (2004). Incentives and restrictions on the right, Vol. 2 revised and enlarged. Moscow, Jurist.

Markov, B. V. Philosophy: Textbook for universities. Standard third-generation. St. Petersburg, S-Pb.

Medushevsky, A. N. (1993). The history of Russian sociology. Textbook for high schools. Moscow.

Miroschnik, S. V. (2003). The theory of legal stimulation: Synopsis of dissertation for the degree of Doctor of Laws. Rostov-on-Don.

Navalny, S. V., \& Romanenko, E. A. (2009). Continuity in the development of political and legal thought. The philosophy of law, 5, 82-87.

Novgorodtsev, P. I. (1911). On the social ideals. Moscow.

Presidential Decree Russian Federation. (1998). from 01.07.1998 N 757 (ed. of 07.09.2010) «On the restoration of the Order of St. Andrew the Apostle» (July 1, 1998). Russian legislation the Assembly, N 27, 06.07.1998, p. 3151.

Presidential Decree Russian Federation. (2010). from 07.09.2010 N 1099 (ed. by 30.04.2015) «On Measures to Improve the Russian Federation state award system». Russian legislation the Assembly, 13.09.2010, N 37, p. 4643.

Putin, V. V. (2015). Message from the President of the Russian Federation Federal Assembly, the 12/03/2015. Retrieved from http://kremlin.ru/events/president/news/50864

Radishchev, A. N. (1949). About statute. In the book.: Selected Philosophical Works. Moscow, Politizdat.

Semenova, I. Y. (2014). Theoretical bases specifications of legal incentives mechanism and legal restrictions in russian family law. Bulletin of Chuvash University, (1), 297-303.

Sharapova, T. A. (2007). The history of legal and political doctrines: Lecture notes. Moscow, Prior-izdat.

Sorokin, P. A. (1914). Crime and punishment, and reward achievement. Sociological study of basic forms of social behavior and morality. Moscow, S-Pb.

Strokin, A. A. (2008). Legal promotion in the history of legal science and practice. Bulletin of Omsk University. «Right» Series, 4(17), 11-14.

The decrees of the Soviet power. (1957). Volume I. October 25, 1917 - March 16, 1918. Moscow, State Publishing House political literature.

\section{Copyrights}

Copyright for this article is retained by the author(s), with first publication rights granted to the journal.

This is an open-access article distributed under the terms and conditions of the Creative Commons Attribution license (http://creativecommons.org/licenses/by/4.0/). 